\title{
UPAYA MENINGKATKAN HASIL BELAJAR PKn MELALUI MODEL PEMBELAJARAN KOOPERATIF TIPE STUDENT TEAM ACHIEVEMENT DIVISION (STAD) DI KELAS IV SD NEGERI 10 TANJUNG BATU
}

\author{
SULASTRI \\ (SDN 10 TANJUNG BATU)
}

\begin{abstract}
ABSTRAK
Penelitian ini bertujuan untuk meningkatkan hasi belajar PKn melalui model pembelajaran Kooperatif Tipe STAD di Kelas IV SDN 10 Tanjung Batu. Penelitian ini merupakan penelitian kuantitatif. Subjek dari penelitian ini adalah siswa kelas IV SDN 10 Tanjung Batu. Metode pengumpulan data adalah dengan melakukan observasi dan pembagian tes tertulis terhadap siswa. Pada siklus I indikator keberhasilan nilai siswa adalah ada 17 siswa yang telah mencapai KKM prosentase ketuntasan adalah 62,96 \% cukup. Sedangkan pada Siklus II indikator keberhasilan nilai siswa adalah 24 yang telah mencapai KKM 70 prosentase ketuntasan adalah $88,88 \%$ kategori Sangat Tinggi. Berarti ketuntasan belajar telah melampaui 75\%, indikator keberhasilan pembelajaran telah tercapai yaitu lebih dari $75 \%$ siswa Kelas IV telah mencapai Kriteria ketuntasan Minimal 70. Dengan demikian dapat disimpulkan bahwa pembelajaran dengan pembelajaran kooperatif tipe STAD dapat meningkatkan hasil belajar PKn di kelas IV SD Negeri 10 Tanjung Batu.
\end{abstract}

Kata Kunci : PKn, Hasil Belajar, Pembelajaran STAD

\section{PENDAHULUAN}

Pembelajaran PKn merupakan mata pelajaran yang memfokuskan pembentukn diri yang beragam dari segi agama, sosial kultur, bahasa, usia, suku, bangsa dan untuk menjadi warga negara indonesia yang cerdas, terampil dan berkarakter yang diamatkan oleh pancasila dan UUD 1945. Fungsinya adalah sebagai wahana untuk membentuk warga negara yang cerdas, terampil, berkarakter, yang setia kepada bangsa dan negara Indonesia dengan merefleksikan dirinya dalam kebiasaan berpikir dan bertindak sesuai dengan amanat Pancasila dan UUD 1945.

Pendidikan berperan penting bagi manusia dalam kehidupan sehari-hari, karena pendidikan sangat besar pengaruhnya terhadap perkembangan manusia dalam seluruh aspek kehidupan. Manusia tumbuh dan berkembang melalui belajar. Dalam kegiatan belajar-mengajar banyak faktor yang menentukan keberhasilan belajar. Keberhasilan belajar tidak terlepas dari peran guru dalam pembelajaran 
guru menjadi peran utama menciptakan situasiyang edukatif, yaitu interaksi antara guru dan siswa, siswa dengan siswa, dan dengan sumber pembelajaran. Untuk terwujudnya proses pembelajaran yang seperti itu sudah barang tentu menuntut adanya upaya guru mengaktualisasikan kompetensinya secara profesional, utamanya dalam aspek metodologis.

Berdasarkan masalah itu peneliti menyadari sepenuhnya masalah-masalah yang selalu muncul dalam kegiatan pembelajaran. Kadang-kadang guru menjadi bingung dalam menentukan model pembelajaran atau model mengajar apa yang akan digunakan dalam proses pembelajaran. Harapan untuk memiliki siswa yang cerdas, dan terampil secara aktif dan kreatif, sehingga hasil yang memuaskan pada setiap tes kadang tidak tercapai. Kenyataan yang dijumpai malah sebaliknya. Siswa kurang aktif dalam pembelajaran, kurang bersemangat dalam menerima pelajaran, serta kurang percaya diri, dalam menjawab pertanyaan dari guru, sehingga mengakibatkan hasil prestasi yang rendah dan mengecewakan. Itu menandakan bahwa pembelajaran dapat dikatakan belum berhasil. Hal ini terbukti dari hasil evaluasi nilai siswa pada mata pelajaran PKn sangat rendah karena tidak mencapai KKM yang telah ditetapkan.

Setelah dilakukan analisa, hasil ulangan harian siswa kelas IV yang berjumlah 27 orang didapat data hasil belajar sebagai berikut : 4 siswa terlampui $(14.81 \%)$, 6 siswa tercapai $(22,22 \%)$, dan 17 siswa tidak tercapai $(62,96 \%)$, siswa yang telah mencapai KKM 70 ada 10 siswa secara klasikal prosentase ketuntasan adalah 37,03. Untuk mengatasi hal tersebut di atas, guru perlu mengoptimalkan pembelajaran PKn salah satu alternatif yang dapat dilakukan ialah dengan menggunakan model pembelajaran tipe Student Team Achievement Division (STAD). Metode tipe Student Team Achievement Division (STAD) menerapkan siswa aktif. Siswa ditempatkan dlam tim belajar beranggotakan empat orang yang merupakan campuran menurut tingkat kinerjanya, jenis kelamin, atau suku. Kegiatan ini merupakan suatu proses dinamis dimana seorang anak memperoleh informasi dan pengetahuan yang kelak dijadikan landasan dasar pengetahuannya dalam proses belajar berikutnya dikemudian hari. Hal ini juga diharapkan kepada siswa agar lebih tertarik terhadap mata pelajaran PKn sehingga bisa cepat dikuasai hingga hasil belajarnya dapat memenuhi dari standar KKM yang telah ditentukan.

Dari latar belakang di atas maka tujuan penelitian ini adalah "Meningkatkan Hasil Belajar Siswa Dalam Pembelajaran PKn dengan Menggunakan Model Pembelajaran Kooperatif Tipe Student Team Achievement Division (STAD)".

\section{Hasil Belajar}

Menurut Degeng (Wena, 2009: 6) "Hasil pembelajaran adalah semua efek yang dapat dijadikan sebagai indikator tentang nilai dari penggunaan strategi pembelajaran dibawah kondisi yang berbeda". Sedangkan Mulyasa (2009:212) menyebutkan bahwa "hasil belajar merupakan prestasi belajar peserta didik secara 
keseluruhan yang menjadi negara kompetensi dasar dan derajat perubahan perilaku yang bersangkutan".

\section{Model Pembelajaran Kooperatif Tipe STAD}

Pembelajaran model koooperatif tipe STAD merupakan" salah satu pembelajaran kooperatif yang diterapkan untuk menghadapi kemampuan siswa yang heterogen. Dimana model ini dipandang sebagai metode yang paling sederhana dan langsung dari pendekatan pembelajaran kooperatif. Metode ini paling awal ditemukan dan dikembangkan oleh para peneliti pendidikan di John Hopkins Universitas Amerika Serikat dengan menyediakan suatu bentuk belajar kooperatif. Di dalamnya siswa diberi kesempatan untuk melakukan kolaborasi dan elaborasi dengan teman sebaya dalam bentuk diskusi kelompok untuk memecahkan suatu permasalahan" (Arindawati, 2004: 83 - 84).

\section{METODE}

Lokasi Penelitian adalah SD Negeri 10 Tanjung Batu beralamat di Jl. Merdeka Desa Tanjung Batu Seberang Kec. Tanjung Batu Kabupaten Ogan Ilir Provinsi Sumatera Selatan. Pengumpulan data dilakukan dengan menggunakan observasi dan tes. Teknik analisa data menggunakan rumus teknik proporsi dengan rumus : $\mathrm{D}=[\mathrm{A}$ / N ] x $100 \%$, Dimana (D :prosentase siswa yang tuntas, A :Jumlah siswa yang tuntas, dan N :Jumlah seluruh siswa (Sudjana, 2010). Hasil analisis data disajikan dalam bentuk data, table dangrafik untuk memudahkan dalam membaca data dan memprediksi kesimpulan apa yang diambil dari penelitian yang dilakukan.

\section{HASIL PENELITIAN DAN PEMBAHASAN}

\section{Siklus I Pertemuan Ke 1}

Hasil Penelitian Peningkatan Hasil Belajar Siswa Akhir Siklus I dan Siklus II Sebelum tindakan aktual dilaksanakan dalam pembelajaran di kelas, terlebih dahulu dilakukan persiapan secara baik, antara lain ;

Membuat skenario pembelajaran dengan penggunaan model pembelajaran kooperatif tipe STAD dengan langkah-langkah pembelajaran yang berisi langkah-langkah kegiatan pembelajaran PKn. Menyiapkan sarana prasarana pembelajaran yang mendukung terlaksananya tindakan pembelajaran, seperti buku sumber rujukan, menyusun materi ajar,whiteboard, kertas, spidol, menyiapkan nomor dan lain sebagainya. Sebelum guru melakukan tindakan terlebih dahulu guru menyusun RPP terlampir.

\section{Pelaksanaan}

Melaksanakan seluruh rencana yang telah dibuat pada tahap sebelumnya, dan melaksanakan langkah-langkah baru secara fleksibel yang dianggap penting dalam setiap kegiatan yang telah direncanakan, termasuk dalam menyajikan 
materi pelajaran sesuai dengan skenario yang telah dibuat dikembangkan sesuai kebutuhan pembelajaran.

Pada saat guru memasuki kelas terlebih dahulu guru mengucapkan salam, dan berdoa bersama-sama. Sebelum memulai pelajaran guru memberikan semangat dan penguatan dengan cara menyanyikan lagu-lagu wajib nasional, atau membacakan ayat-ayat pendek dalam Al-Qur'an. Hal ini dilakukan guna untuk merangsang semangat siswa dalam belajar. Ketika guru menyajikan materi pelajaran dengan menggunakan model pembelajaran kooperatif tipe STAD siswa mulai bertanya-tanya mengenai apa itu model pembelajaran kooperatif tipe STAD, bagaimana cara belajarnya, siswa mulai bertanya kepada guru, barula guru memulai menjelaskan langkah-langkah model pembelajaran kooperatif tipe STAD. Siswa baru mengerti ternyata model pembelajaran kooperatif tipe STAD itu adalah model pemnelajaran dengan cara berkelompok. Pada proses kegiatan inti berlangsung guru dapat guru meminta siswa membuka buku pelajaran dan menunjuk beberapa siswa untuk membacakan isi materi guru menceritakan gambaran bangsa Indonesia pada saat zaman penjajahan, setelah itu guru memberikan tugas kelompok untuk dikerjakan oleh anggota-anggota kelompok. Siswa berdiskusi secara kelompok dan guru mensupervisi kegiatan siswa,guru meminta siswa mempresentasikan hasil diskusi mereka satu kelompok menampilkan hasil diskusi mereka. Kelompok lain diminta untuk mengamati dan menyimak serta memberi saran. Siswa bertanya kepada guru tentang pembelajaran yang belum dimengerti. Setelah diskusi selesai guru memberikan penghargaan bagi setiap kelompok yang menampilkan tampilan yang terbaik ketika berdiskusi di depan kelas. Diakhir pembelajaran barula guru menyimpulkan materi pelajaran.

\section{Evaluasi}

Pada siklus 1 pertemuan ke satu peneliti belum melakukan evaluasi karena materi masih dilanjutkan pada siklus berikutnya.

\section{Refleksi}

Berdasarkan hasil pengamatan dari pelaksanaan pembelajaran ditemukan hal-hal seperti dibawah ini :

a. Proses pembelajaran dengan model pembelajaran kooperatif tipe STAD merupakan pengalaman baru bagi siswa, sehingga kesiapan siswa masih kurang.

b. Minat dan motivasi belajar kurang.

c. Belum terbiasanya siswa mengoptimalkan kemampuan hingga kelihatan masih bingung dalam penggunaan model pembelajaran kooperatif tipe STAD.

Setelah dilihat dari keunggulan dan kelemahannya tersebut, maka harus kita perbaiki pada siklus berikutnya. 
CIVICS EDUCATION AND SOCIAL SCIENSE JOURNAL(CESSJ)

Volume 3 Nomor 1 Edisi Bulan Juni 2021

\section{Siklus I Pertemuan Ke dua}

1. Perencanaan

Sebelum tindakan aktual dilaksanakan dalam pembelajaran di kelas, terlebih dahulu dilakukan persiapan secara baik, antara lain ;

Membuat skenario pembelajaran dengan penggunaan model pembelajaran kooperatif tipe STAD dengan langkah-langkah pembelajaran yang berisi langkah-langkah kegiatan pembelajaran PKn. Menyiapkan sarana prasarana pembelajaran yang mendukung terlaksananya tindakan pembelajaran, seperti buku sumber rujukan, menyusun materi ajar,whiteboard, kertas, spidol, menyiapkan nomor dan lain sebagainya. Sebelum guru melakukan tindakan terlebih dahulu guru menyusun RPP terlampir

\section{Pelaksanaan}

Melaksanakan seluruh rencana yang telah dibuat pada tahap sebelumnya, dan melaksanakan langkah-langkah baru secara fleksibel yang dianggap penting dalam setiap kegiatan yang telah direncanakan, termasuk dalam menyajikan materi pelajaran sesuai dengan skenario yang telah dibuat dikembangkan sesuai kebutuhan pembelajaran.

Pada saat guru memasuki kelas terlebih dahulu guru mengucapkan salam, dan berdoa bersama-sama. Sebelum memulai pelajaran guru memberikan semangat dan penguatan dengan cara menyanyikan lagu-lagu wajib nasional, atau membacakan ayat-ayat pendek dalam Al-Qur'an. Hal ini dilakukan guna untuk merangsang semangat siswa dalam belajar. Ketika guru menyajikan materi pelajaran dengan menggunakan model pembelajaran kooperatif tipe STAD siswa mulai bertanya-tanya mengenai apa itu model pembelajaran kooperatif tipe STAD, bagaimana cara belajarnya, siswa mulai bertanya kepada guru, barula guru memulai menjelaskan langkah-langkah model pembelajaran kooperatif tipe STAD. Siswa baru mengerti ternyata model pembelajaran kooperatif tipe STAD itu adalah model pemnelajaran dengan cara berkelompok. Pada proses kegiatan inti berlangsung guru dapat guru meminta siswa membuka buku pelajaran dan menunjuk beberapa siswa untuk membacakan isi materi guru menceritakan gambaran bangsa Indonesia pada saat zaman penjajahan, setelah itu guru memberikan tugas kelompok untuk dikerjakan oleh anggota-anggota kelompok. Siswa berdiskusi secara kelompok dan guru mensupervisi kegiatan siswa,guru meminta siswa mempresentasikan hasil diskusi mereka satu kelompok menampilkan hasil diskusi mereka. Kelompok lain diminta untuk mengamati dan menyimak serta memberi saran. Siswa bertanya kepada guru tentang pembelajaran yang belum dimengerti. Setelah diskusi selesai guru memberikan penghargaan bagi setiap kelompok yang menampilkan tampilan yang terbaik ketika berdiskusi di depan kelas. Diakhir pembelajaran barula guru menyimpulkan materi pelajaran. 
CIVICS EDUCATION AND SOCIAL SCIENSE JOURNAL(CESSJ)

Volume 3 Nomor 1 Edisi Bulan Juni 2021

\section{Evaluasi}

Pada siklus 1 pertemuan ke dua peneliti telah melakukan evaluasi dengan hasil prosentase ketuntasan adalah $62,96 \%$.

\section{Refleksi}

Berdasarkan hasil pengamatan dari pelaksanaan pembelajaran ditemukan hal-hal seperti dibawah ini :

a. Proses pembelajaran dengan model pembelajaran kooperatif tipe STAD merupakan pengalaman baru bagi siswa, sehingga kesiapan siswa masih kurang.

b. Minat dan motivasi belajar kurang.

c. Belum terbiasanya siswa mengoptimalkan kemampuan hingga kelihatan masih bingung dalam penggunaan model pembelajaran kooperatif tipe STAD.

Setelah dilihat dari kelemahannya tersebut, maka harus kita perbaiki pada siklus berikutnya.

\section{Siklus II}

\section{Pertemuan Ke satu}

a. Perencanaan

Sebelum tindakan aktual dilaksanakan dalam pembelajaran di kelas, terlebih dahulu dilakukan persiapan secara baik, antara lain ;

Membuat skenario pembelajaran dengan penggunaan model pembelajaran kooperatif tipe STAD dengan langkah-langkah pembelajaran yang berisi langkah-langkah kegiatan pembelajaran PKn. Menyiapkan sarana prasarana pembelajaran yang mendukung terlaksananya tindakan pembelajaran, seperti buku sumber rujukan, menyusun materi ajar,whiteboard, kertas, spidol, menyiapkan nomor dan lain sebagainya. Sebelum guru melakukan tindakan terlebih dahulu guru menyusun RPP terlampir

\section{b. Pelaksanaan}

Melaksanakan seluruh rencana yang telah dibuat pada tahap sebelumnya, dan melaksanakan langkah-langkah baru secara fleksibel yang dianggap penting dalam setiap kegiatan yang telah direncanakan, termasuk dalam menyajikan materi pelajaran sesuai dengan skenario yang telah dibuat dikembangkan sesuai kebutuhan pembelajaran.

Pada saat guru memasuki kelas terlebih dahulu guru mengucapkan salam, dan berdoa bersama-sama. Sebelum memulai pelajaran guru memberikan semangat dan penguatan dengan cara menyanyikan lagu-lagu wajib nasional, atau membacakan ayat-ayat pendek dalam Al-Qur'an. Hal ini dilakukan guna untuk merangsang semangat siswa dalam belajar. Ketika guru menyajikan materi pelajaran dengan menggunakan model pembelajaran kooperatif tipe STAD siswa mulai bertanya-tanya mengenai apa itu model pembelajaran 
kooperatif tipe STAD, bagaimana cara belajarnya, siswa mulai bertanya kepada guru, barula guru memulai menjelaskan langkah-langkah model pembelajaran kooperatif tipe STAD. Siswa baru mengerti ternyata model pembelajaran kooperatif tipe STAD itu adalah model pemnelajaran dengan cara berkelompok. Pada proses kegiatan inti berlangsung guru dapat guru meminta siswa membuka buku pelajaran dan menunjuk beberapa siswa untuk membacakan isi materi guru menceritakan gambaran bangsa Indonesia pada saat zaman penjajahan, setelah itu guru memberikan tugas kelompok untuk dikerjakan oleh anggota-anggota kelompok. Siswa berdiskusi secara kelompok dan guru mensupervisi kegiatan siswa,guru meminta siswa mempresentasikan hasil diskusi mereka satu kelompok menampilkan hasil diskusi mereka. Kelompok lain diminta untuk mengamati dan menyimak serta memberi saran. Siswa bertanya kepada guru tentang pembelajaran yang belum dimengerti. Setelah diskusi selesai guru memberikan penghargaan bagi setiap kelompok yang menampilkan tampilan yang terbaik ketika berdiskusi di depan kelas. Diakhir pembelajaran barula guru menyimpulkan materi pelajaran.

\section{c. Evaluasi}

Pada siklus 2 pertemuan ke satu peneliti belum melakukan evaluasi karena materi masih dilanjutkan pada siklus berikutnya.

\section{d. Refleksi}

Setelah dilihat dari keunggulan dan kelemahannya, maka harus kita perbaiki pada siklus berikutnya dengan mengubah kelompok siswa.

\section{Pertemuan Ke dua}

\section{a. Perencanaan}

Sebelum tindakan aktual dilaksanakan dalam pembelajaran di kelas, terlebih dahulu dilakukan persiapan secara baik, antara lain ;

Membuat skenario pembelajaran dengan penggunaan model pembelajaran kooperatif tipe STAD dengan langkah-langkah pembelajaran yang berisi langkahlangkah kegiatan pembelajaran PKn. Menyiapkan sarana prasarana pembelajaran yang mendukung terlaksananya tindakan pembelajaran, seperti buku sumber rujukan, menyusun materi ajar,whiteboard, kertas, spidol, menyiapkan nomor dan lain sebagainya. Sebelum guru melakukan tindakan terlebih dahulu guru menyusun RPP terlampir.

\section{b. Pelaksanaan}

Melaksanakan seluruh rencana yang telah dibuat pada tahap sebelumnya, dan melaksanakan langkah-langkah baru secara fleksibel yang dianggap penting dalam setiap kegiatan yang telah direncanakan, termasuk dalam menyajikan materi pelajaran sesuai dengan skenario yang telah dibuat dikembangkan sesuai kebutuhan pembelajaran. 
Pada saat guru memasuki kelas terlebih dahulu guru mengucapkan salam, dan berdoa bersama-sama. Sebelum memulai pelajaran guru memberikan semangat dan penguatan dengan cara menyanyikan lagu-lagu wajib nasional, atau membacakan ayat-ayat pendek dalam Al-Qur'an. Hal ini dilakukan guna untuk merangsang semangat siswa dalam belajar. Ketika guru menyajikan materi pelajaran dengan menggunakan model pembelajaran kooperatif tipe STAD siswa mulai bertanya-tanya mengenai apa itu model pembelajaran kooperatif tipe STAD, bagaimana cara belajarnya, siswa mulai bertanya kepada guru, barula guru memulai menjelaskan langkah-langkah model pembelajaran kooperatif tipe STAD. Siswa baru mengerti ternyata model pembelajaran kooperatif tipe STAD itu adalah model pemnelajaran dengan cara berkelompok. Pada proses kegiatan inti berlangsung guru dapat guru meminta siswa membuka buku pelajaran dan menunjuk beberapa siswa untuk membacakan isi materi guru menceritakan gambaran bangsa Indonesia pada saat zaman penjajahan, setelah itu guru memberikan tugas kelompok untuk dikerjakan oleh anggota-anggota kelompok. Siswa berdiskusi secara kelompok dan guru mensupervisi kegiatan siswa, guru meminta siswa mempresentasikan hasil diskusi mereka satu kelompok menampilkan hasil diskusi mereka. Kelompok lain diminta untuk mengamati dan menyimak serta memberi saran. Siswa bertanya kepada guru tentang pembelajaran yang belum dimengerti. Setelah diskusi selesai guru memberikan penghargaan bagi setiap kelompok yang menampilkan tampilan yang terbaik ketika berdiskusi di depan kelas. Diakhir pembelajaran barula guru menyimpulkan materi pelajaran.

\section{c. Evaluasi}

Pada siklus 2 pertemuan ke dua peneliti telah melakukan evaluasi dengan hasil prosentase ketuntasan adalah $88,88 \%$.

\section{d. Refleksi}

Secara umum pada siklus kedua ini terlihat motivasi dan semangat siswa dalam pembelajaran lebih meningkat dibanding siklus pertama. Pada siklus kedua ini tampak siswa mengalami peningkatan pemahaman materi yang dipelajari. Kemampuan siswa mengembangkan materi lebih luas yang berdampak terhadap peningkatan hasil belajar. Hal ini menunjukan bahwa siswa sudah memahami dan menikmati pembelajaran metode diskusi

Berdasarkan pada pengamatan dalam proses pembelajaran ditemukan halhal berikut :

1. Siswa mulai berani mengemukakan pendapat pada kelompoknya karena merasa leluasa dalam berinteraksi.

2. Siswa menyampaikan gagasan yang bervariasi sehingga dalam penyelesaian masalah memerlukan waktu yang agak lama.

3. Siswa sudah terbiasa dengan pembelajaran model pembelajaran kooperatif tipe STAD, sehingga pembelajaran berlangsung sesuai dengan rencana pembelajaran. 
4. Pemberian penghargaan kepada siswa yang aktif menumbuhkan semangat bagi yang lain dan mendorong terhadap penguasaan materi.

Setelah dilihat dari hasil evaluasi siklusi II pertemuan ke dua hasil yang didapat siswa telah mencapai KKM yang telah ditetapkan yaitu 87,87 \% dengan demikian maka proses pembelajaran dengan menggunakan model pembelajaran kooperatif tipe STAD telah berhasil dilakukan. Maka penelitian ini tidak perlu dilanjutkan lagi.

\section{Pembahasan Hasil Penelitian \\ Hasil Penelitian Siklus 1}

Hasil penelitian pada siklus I berupa data hasil olah nilai tes terhadap siswa diakhir siklus I untuk memperoleh nilai hasil belajar siswa selama dua kali pertemuan.

\section{Data Hasil Belajar PKn Siswa Siklus I}

Data hasil belajar PKn siswa pada akhir siklus I dapat dilihat pada tabel 5 berikut :

Tabel 5 : Hasil Belajar Siswa pada Akhir Siklus I

\begin{tabular}{|c|c|c|c|c|}
\hline No & Nilai & Jumlah Siswa & Tuntas & $\begin{array}{c}\text { Tak } \\
\text { Tuntas }\end{array}$ \\
\hline 1 & $<49$ & 3 & - & 3 \\
\hline 2 & $50-59$ & 3 & - & 3 \\
\hline 3 & $60-69$ & 4 & - & 4 \\
\hline 4 & $70-79$ & 10 & 10 & - \\
\hline 5 & $80-89$ & 4 & 4 & - \\
\hline 6 & $90-100$ & 3 & 3 & - \\
\hline & Jumlah & 27 & 17 & 10 \\
\hline
\end{tabular}

Berdasarkan tabel 5 di atas menunjukan hasil belajar siswa setelah siklus I telah memenuhi standar ketuntasan minimum 70 sebesar $62,96 \%$. Nilai siswa tidak menyebar merata, sebagian besar pada kisaran 70-79 dengan nilai rata-rata 37,03 $\%$ maka dapat dikatakan pada siklus I hasil belajar siswa belum optimal dan oleh karena itu perlu ditingkatkan pada siklus selanjutnya. Secara rinci dapat dilihat dalam gambar 2 di bawah ini : 


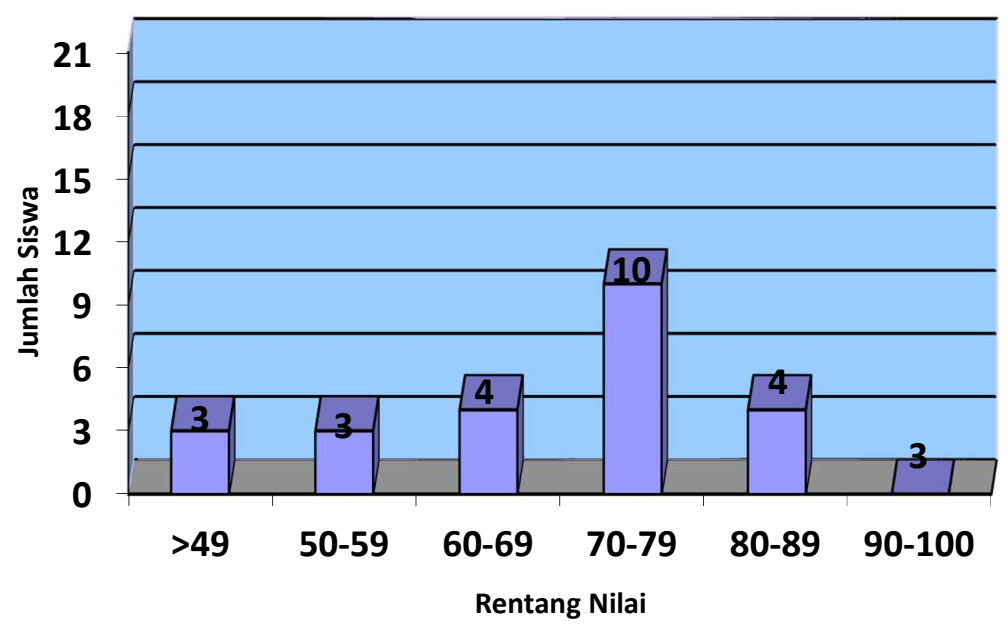

Tabel : 6 Indikator keberhasilan Nilai akhir siswa siklus I

\begin{tabular}{|c|c|c|c|}
\hline No & Prosentase Ketuntasan & Katagori & Nilai Akhir \\
\hline 1 & $\geq 80 \%$ & sangat tinggi & 7 \\
\hline 2 & $70 \%-79 \%$ & Tinggi & 10 \\
\hline 3 & $60 \%-69 \%$ & Cukup & 4 \\
\hline 4 & $50 \%-59 \%$ & Kurang & 3 \\
\hline 5 & $\leq 49$ & sangat kurang & 3 \\
\hline
\end{tabular}

Indikator keberhasilan nilai siswa adalah 3 siswa dengan nilai sangat kurang, 3 siswa dengan kurang, 4 siswa memperoleh nilai cukup, 10 siswa memperoleh nilai tinggi dan 3 siswa memperoleh nilai sangat tinggi rata-rata siswa memperoleh nilai tinggi, jadi jumlah siswa yang telah melampaui KKM 70 ada 17 siswa prosentase ketuntasan adalah $62,96 \%$ : cukup

\section{Refleksi Siklus I}

Berdasarkan hasil pengamatan dari pelaksanaan pembelajaran ditemukan hal-hal seperti dibawah ini :

- Proses pembelajaran dengan model pembelajaran kooperatif tipe STAD merupakan pengalaman baru bagi siswa, sehingga kesiapan siswa masih kurang.

- Minat dan motivasi kurang.

- Belum terbiasanya siswa mengoptimalkan kemampuan hingga kelihatan masih bingung dalam penggunaan model pembelajaran kooperatif tipe STAD. 
CIVICS EDUCATION AND SOCIAL SCIENSE JOURNAL(CESSJ)

Volume 3 Nomor 1 Edisi Bulan Juni 2021

\section{Hasil Penelitian Siklus II}

Data yang diperoleh dalam siklus II berupa data hasil olah nilai tes terhadap siswa diakhir siklus II untuk memperoleh nilai hasil belajarnya.

Data Hasil Belajar PKn Siswa Siklus II

Data hasil belajar PKn siswa pada akhir siklus II dapat dilihat pada tabel 8 berikut:

Tabel 8: Data Hasil Belajar Siswa pada Akhir Siklus II

\begin{tabular}{|c|c|c|c|c|}
\hline No & Nilai & Jumlah Siswa & Tuntas & $\begin{array}{c}\text { Tak } \\
\text { Tuntas }\end{array}$ \\
\hline 1 & $<49$ & - & - & - \\
\hline 2 & $50-59$ & - & - & - \\
\hline 3 & $60-69$ & 3 & - & 3 \\
\hline 4 & $70-79$ & 8 & 8 & - \\
\hline 5 & $80-89$ & 10 & 10 & - \\
\hline 6 & $90-100$ & 6 & 6 & - \\
\hline & Jumlah & 27 & 24 & 3 \\
\hline
\end{tabular}

Berdasarkan tabel 8 di atas menunjukan hasil belajar siwa setelah siklus II telah memenuhi standar ketuntasan belajar minimum 70 sebesar $88,88 \%$. Nilai siswa sebagian besar pada kisaran 80-89 dengan nilai 37,03 \% yang dikategorikan tinggi, jadi jumlah siswa yang mencapai nilai KKM 70 adalah 24 siswa prosentase ketuntasan adalah 88,88 maka dapat dikatakan pada siklus II hasil belajar siswa sudah optimal. Secara rinci dapat dilihat dalam gambar 4 berikut :

Gambar 2 : Grafik Hasil Belajar PKn Siswa pada Siklus II 


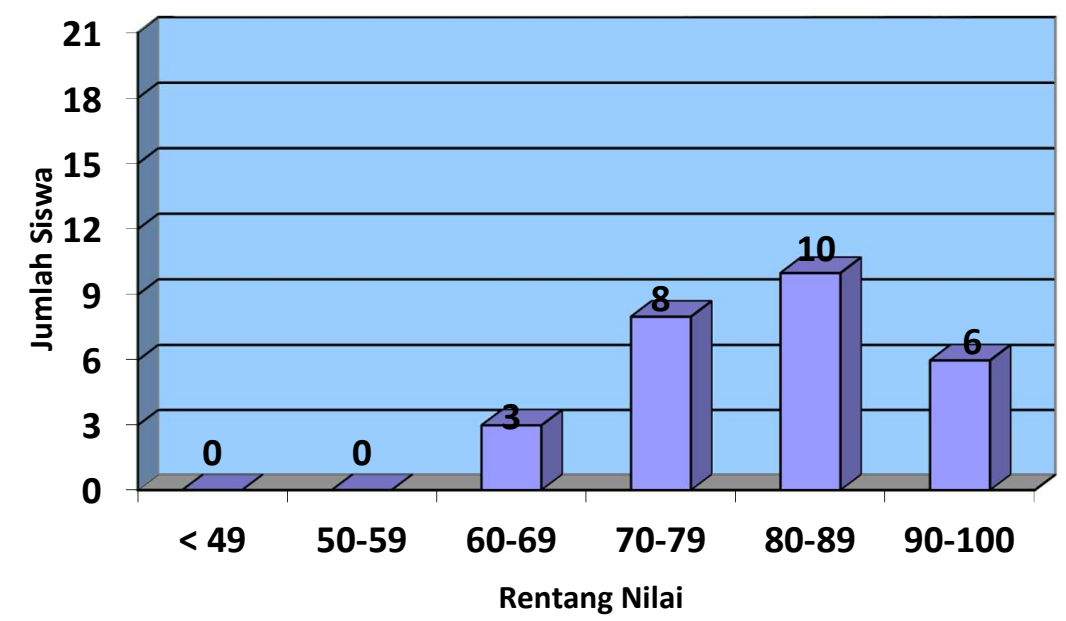

T abel 9 : Indikator keberhasilan Nilai akhir siswa siklus II

\begin{tabular}{|c|c|c|c|}
\hline No & Prosentase Ketuntasan & Kategori & Jumlah Siswa \\
\hline 1 & $\geq 80 \%$ & sangat tinggi & 16 \\
\hline 2 & $70 \%-79 \%$ & Tinggi & 8 \\
\hline 3 & $60 \%-69 \%$ & Cukup & 3 \\
\hline 4 & $50 \%-59 \%$ & kurang & 0 \\
\hline 5 & $\leq 49$ & sangat kurang & 0 \\
\hline
\end{tabular}

Indikator keberhasilan nilai siswa adalah 3 siswa dengan nilai cukup, 8 siswa dengan nilai tinggi dan 16 siswa memperoleh nilai sangat tinggi rata-rata siswa memperoleh nilai sangat tinggi, jumlah siswa tuntas adalah 24 siswa prosentase ketuntasan adalah 88,88 kategori Sangat Tinggi.

\section{Refleksi Siklus II}

Secara umum pada siklus kedua ini terlihat motivasi dan semangat siswa dalam pembelajaran lebih meningkat dibanding siklus pertama. Pada siklus kedua ini tampak siswa mengalami peningkatan pemahaman materi yang dipelajari. Kemampuan siswa mengembangkan materi lebih luas yang berdampak terhadap peningkatan hasil belajar. Hal ini menunjukan bahwa siswa sudah memahami dan menikmati pembelajaran model pembelajaran kooperatif tipe STAD hal berikut :

Berdasarkan pada pengamatan dalam proses pembelajaran ditemukan hal- 
- Siswa mulai berani mengemukakan pendapat pada kelompoknya karena merasa leluasa dalam berinteraksi.

- Siswa menyampaikan gagasan yang bervariasi sehingga dalam penyelesaian masalah memerlukan waktu yang agak lama.

- Siswa sudah terbiasa dengan pembelajaran model pembelajaran kooperatif tipe STAD, sehingga pembelajaran berlangsung sesuai dengan rencana pembelajaran.

- Pemberian penghargaan kepada siswa yang aktif menumbuhkan semangat bagi yang lain dan mendorong terhadap penguasaan materi.

\section{Pembahasan}

\section{Hasil Penelitian Peningkatan Hasil Belajar Siswa Akhir Siklus I dan Siklus II}

Proses pembelajaran yang telah dilakukan, telah mengarah pada peningkatan keaktifan belajar siswa dan akhirnya berpengaruh pada hasil belajar siswa. Berdasarkan data nilai yang diperoleh dari tes yang diberikan pada siswa pada akhir setiap siklus pada penelitian tindakan kelas ini, pembelajaran model pembelajaran kooperatif tipe STAD menunjukan adanya peningkatan pada hasil belajar siswa. Peningkatan hasil belajar siswa pada mata pelajaran PKn secara jelas dapat dilihat pada tabel 10 berikut ini :

Tabel 10 : Data Peningkatan Hasil belajar Siswa akhir siklus I dan siklus II

\begin{tabular}{|c|c|c|c|c|}
\hline No & $\begin{array}{c}\text { Prosentase } \\
\text { Ketuntasan }\end{array}$ & Kategori & $\begin{array}{c}\text { Nilai Akhir } \\
\text { Siklus 1 }\end{array}$ & $\begin{array}{c}\text { Nilai Akhir } \\
\text { Siklus II }\end{array}$ \\
\hline 1 & $\geq 80 \%$ & sangat tinggi & 7 & 16 \\
\hline 2 & $70 \%-79 \%$ & tinggi & 10 & 8 \\
\hline 3 & $60 \%-69 \%$ & cukup & 4 & 3 \\
\hline 4 & $50 \%-59 \%$ & kurang & 3 & 0 \\
\hline 5 & $\leq 49$ & sangat kurang & 3 & 0 \\
\hline
\end{tabular}

Pada siklus I Indikator keberhasilan nilai siswa adalah jumlah siswa yang tuntas mencapai KKM 70 adalah 17 siswa prosentase ketuntasan klasikal adalah 62,96\% kategori: cukup

Sedangkan pada Siklus II Indikator keberhasilan siswa yang tuntas mencapai KKM 70 adalah 24 siswa prosentase ketuntasan klasikal adalah 88,88 \% kategori: Sangat Tinggi.

Indikator keberhasilan adalah 75\% siswa mencapai KKM 70 sedangkan dalam penelitian ini $88,88 \%$ siswa telah mencapai KKM jadi penelitian ini telah berhasil meningkatkan hasil belajar PKn Siswa kelas VI melalui model pembelajaran kooperatif tipe STAD. 
CIVICS EDUCATION AND SOCIAL SCIENSE JOURNAL(CESSJ)

Volume 3 Nomor 1 Edisi Bulan Juni 2021

Tabel 11: Peningkatan Hasil belajar

\begin{tabular}{|c|c|c|}
\hline Penelitian & Tuntas \% & Tidak Tuntas \\
\hline \hline Pra Penelitian & 37,03 & 62,97 \\
\hline Akhir Siklus I & 62,96 & 41,38 \\
\hline Akhir Siklus II & 88,88 & 11,12 \\
\hline
\end{tabular}

Berdasarkan tabel 11 di atas, dapat dilihat hasil peningkatan ketuntasan secara klasikal pra penelitian 37,03 \% ke siklus I terjadi peningkatan hasil belajar menjadi $62,96 \%$, ke siklus II menjadi $88,88 \%$ jadi pembelajaran dengan menggunakan metode kooperatif tipe STAD dinyatakan Berhasil karena sudah mencapai tingkat ketuntasan diatas $75 \%$ yaitu 88,88\%. Peningkatan hasil belajar yang terjadi dikarenakan siswa lebih cepat mengingat materi pelajaran dengan penerapan pembelajaran metode kooperatif tipe STAD dan proses pembelajaran disesuaikan dengan rencana pelaksanaan pembelajaran yang telah disusun. Siswa terlihat sangat terbantu dengan adanya metode kooperatif tipe STAD.

Dalam proses pembelajaran siswa dapat mendengar, melihat dan mencari sendiri jawaban dari permasalahan yang mereka hadapi yang akhirnya mereka dapat dengan mudah menyelesaikan permasalahan dan soal-soal yang diberikan dengan penerapan pembelajaranini. Dengan demikian tampak bahwa penerapan pembelajaran dengan metode kooperatif tipe STAD dapat meningkatkan hasil belajar siswa pada mata pelajaran PKn Secara lebih rinci dapat dilihat pada gambar 3.di bawah ini :

Gambar3 : Grafik Peningkatan Hasil Belajar

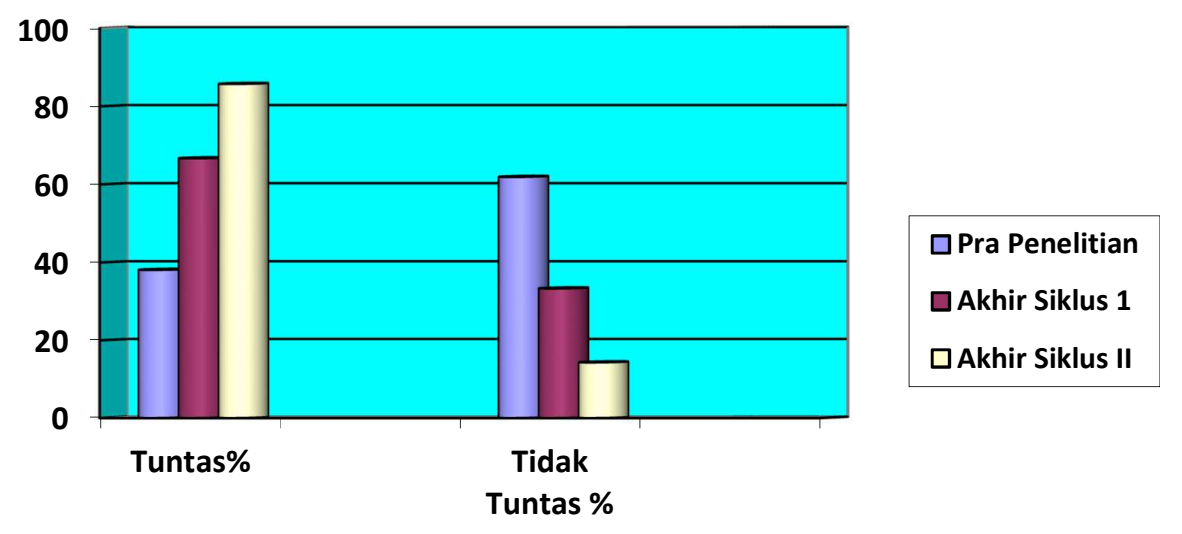

Pada gambar 3 menunjukan bahwa nilai rata-rata yang dicapai sebagai hasil belajar siswa pada siklus II lebih tinggi dibanding siklus I demikian juga dengan ketuntasan klasikalnya. 
Hasil penelitian ini senada dengan apa yang dikemukakan oleh Slavin dalam buku Hartati, bahwa banyak keuntungan psikologis yang dapat diraih dengan menggunakan model pembelajaran kooperatif tipe STAD antara lain : Dapat mengembangkan prestasi siswa, rasa percaya diri siswa meningkat, memberikan perkembangan yang berkesan

Hal ini senada pula dengan pendapat dari Nurhadi ia mengemukakan bahwa, model pembelajaran kooperatif tipe STAD banyak membawa keuntungan dan kebaikan dalam proses belajar mengajar yaitu : Meningkatkan kepekaan dan kesetiakawanan sosial,siswa saling belajar mengenai sikap, keterampilan, informasi, memudahkan siswa melakukan penyesuaian.

\section{SIMPULAN}

Dari data yang telah dibahas pada siklus 1 dengan hasil belajar tuntas 62,96 $\%$ tidak tuntas 34,29\% prosentase keberhasilan belajar siklus 1 adalah 62,96\% peningkatan hasil belajar dari pra siklus $25,93 \%$, siklus 2 diperoleh hasil belajar dengan rincian ketuntasan hasil belajar 88,88 \% yang tidak tuntas 10,35\% peningkatan dari siklus $125,92 \%$ jadi dapat disimpulkan bahwa penelitian memang dapat meningkatkan hasil belajar siswa pada mata pelajaran PKn melalui model pembelajaran kooperatif tipe STAD pada siswa SD Negeri 10 Tanjung Batu.

\section{REFERENSI}

(2010). Model Pembelajaran Kepala Bernomor

Arindawati. (2004). Pembelajaran Kontekstual dan Penerapaanya dalam KBK. Malang : Universitas Negeri Malang

Mulyasa. (2009). Dasar Dasar Kependidikan. Bandung : Transito

Pendidikan Nasional Nomor 22 Tahun 2006 tentang Standar Isi. Jakarta : Depdiknas

Sudjana, Nana. (2001). Penilaian Hasil Belajar Mengajar. Bandung : Remaja Rosda Karya

Wena, Made. (2009). Strategi Pembelajaran Inovatif Kontemporer. Jakarta : Bumi Aksara 